\title{
Place of Observation Skill in 5. Grade Social Studies Textbooks
}

\author{
Hülya KARAÇALI TAZE' \\ Sinop University, Sinop, TURKEY
}

1 Assist. Prof. Dr. Sinop University, Faculty of Education, Department of Turkish and Social Sciences Education, Sinop, TURKEY. hkaracali[at]sinop.edu.tr. ORCID: 0000-0002-6592-0807

\begin{abstract}
The aim of this study is to comparatively examine the status of observation skills in the questions contained in the 2007 and 2020 fifth grade social studies textbooks published after the 2005 and 2018 curriculums. The reason for choosing the fifth class as a class level is that observation skills were included at this class level in both 2005 and 2018 SSCEC as a direct skill. In this research, the document review method was used from qualitative research patterns. The data collection tools of the research constitute two different fifth-grade social studies textbooks, one published in 2007 and the other in 2020. These documents are available from schools and the EBA online education platform. The data was analyzed using descriptive analysis technique. As a result of the research, it was determined that twenty-three questions about observation skills were included in the 2007 edition of the social studies textbook and ten questions were included in the 2020 edition of the textbook. However, it has been concluded that the textbook that contains the highest level of questions is the 2020 edition textbook. Fifth - grade social studies textbooks may include questions about all levels of observation skills, even if they differ in quantity over many years.
\end{abstract}

\section{Keywords}

Social Studies, Skills, Textbooks, Observation

To cite this article: Taze Karaçal, H. (2021). Place of Observation Skill in 5, Grade Social Studies Textbooks. Review of International Geographical Education (RIGEO), 11(1), 100-117. doi: 10.33403rigeo.840610 
One of the courses in which the aim of educating individuals who are healthy and efficiently devoted to society and developing the abilities of these individuals (Güven, 2007) can be realized is the social studies course. 21. century, especially in relation to talent development. skills have become more important in the century and 21. century the inclusion of skills described as skills in the curriculum is one of the important developments in the field of education. Skill is defined as" the predisposition in students to be able to do a job or process a subject, which is designed to be acquired, developed and transferred to life in the learning process " (Ata, 2015, P 38). When examining the Social Studies course education curriculum ([SSCEC], 2018), it is possible to see the characteristics of individuals who can adapt to society and develop their abilities within competencies, values and skills. However, skills are also among the basic elements of the SSCEC, which was prepared in accordance with the constructivist understanding in 2005. It is understood from the expression that at least one skill will be acquired in each learning area where skills are important in social studies education.

In 2018, updates were made to the SSCEC, and one of these updates is related to skills. In 2005 and 2018, the number of skills increased from fifteen in 2005 to twenty-seven in 2018. 2005 (Minestry of National Education, 2005, p. 47) the skills included in the program in the year are as follows, and the first nine of them will be given together with other courses, and the last six are skills specific to the social studies course:

1.Critical thinking skills

2.Creative thinking skills

3.Communication skills

4.Research skills

5.Problem solving skills

6.Decision making skills

7.Ability to use information technology

8.Entrepreneurial skills

9.Ability to use Turkish correctly, beautifully and effectively

10.0bservation skill

11.Ability to perceive place

12.Ability to perceive time and chronology

13.Ability to perceive change and continuity

14.Social participation skills

15.Empathy skill

In 2018 (MoNE, 2018, p. 9), the following skills are included in the program:

1. Research

2. Environmental literacy

3. Perception of change and continuity

4. Digital literacy

5. Critical thinking

6. Empathy

7. Financial literacy

8. Entrepreneur

9. Observation 

10. Map literacy
11. Law literacy
12. Communication
13. Collaboration
14. Notice pattern expression and prejudice
15. Using evidence
16. Decision making
17. Location analysis
18. Media literacy
19. Perceive place
20. self control
21. Political literacy
22. Problem solving
23. Social involvement
24. Drawing and interpreting tables, charts and diagrams
25. Correct, beautiful and effective use of Turkish
26. Innovative thinking
27. Perceive time and chronology

As can be seen from the lists above, almost all of the skills included in 2005 were included in the curriculum in 2018, while some skills not included in 2005 were included in the curriculum in 2018. One of the common skills in both the 2005 and 2018 SSCEC is observation skill. Skills included in 2005 but not included in 2018 are skills to use creative thinking. But 2018 is not contained in 2005, located in seven literacy skills (environment, digital, financial, map, law, media, and politics), cooperation, expression and prejudice to notice, using evidence, location analysis, self-control, tables, graphs, and diagrams, drawing skills, and innovative thinking interpreting. One of the thirteen skills included in both programs is observation skill. However, the observation skill was only included in the fifth grade as a direct skill in 2005, while in 2018 the related skill is given at all grade levels within the "People, Places and environments" learning area. Although it is stated that the observation skill will be acquired at all grade levels of the relevant learning area in the 2018 SSCEC, it is stated only in the fifth-grade learning area in the description of which skill will be acquired under the learning areas. Therefore, both located in the same grade level in programs due to the skill of comparison can be done, and few studies on this subject have been found (Taş, 2008; Yıldız, 2016; Ablak, 2017; Çelikkaya and Kürümlüoğlu, 2017; Filoğlu, 2018; Kıbıcl, 2019) due to this skill is worth checking out. For this reason, the aim of this research is to comparatively examine the status of observation skills in the questions contained in the fifth-grade social studies textbooks published in 2007 and 2020. Within the scope of this purpose, in the research process, we tried to look for answers to the following sub-problems;

1. How is it that observation skills are included in the questions contained in the social studies textbook published in 2007?

2. How is it that observation skills are included in the questions contained in the social studies textbook published in 2020 ?

3. Social studies textbooks published in 2007 and 2020 what is the situation compared to questions about observation skills. 
Observation is the examination of events and facts by different methods (MoNE, 2005). According to the Turkish language institution (2020), observation is "careful and planned consideration and examination of an object, event or fact in order to know its qualities". In both definitions, the work of examination comes to the fore. In order for this examination to be carried out, there must be a sense of curiosity. Observation skills can be improved by the sense of curiosity that exists in young children (MoNE, 2005).

There are some benefits to observing. These are listed below (Tan and Temiz, 2003):

- It leads children to be curious,

- By observing similarities and differences, classification, identification and modification skills are developed,

- Observation of successive events helps to develop the concept,

- Enables development of information,

- It reveals his excitement for research.

In order to improve the observation skills of students at the secondary school level, it is necessary to focus mainly on "the ability to pay attention to events and phenomena around them, their awareness" (MoNE, 2005). Students who study events in the immediate vicinity have knowledge about the environment in which they are located (Demircioğlu and Akengin, 2012). Making observations in real life in relation to the subjects learned in the classroom plays an important role in understanding what geography is, how it is used in daily life, and how it contributes to the solution of problems in the world (Üker, 2009).

In the 2005 SSCEC, the observation skill is cascaded as follows:

- Attention to events and phenomena around it

- Detect events and phenomena around it

- Accurately and impartially identify events and facts around it

- Explain the causes and consequences of surrounding events and cases

- Be able to question the reasons and predict the consequences of what they observe

- Ability to establish relationships between events and phenomena, reveal similar or different aspects

- Record and transmit what you observe

- Ability to compare and link what they observe with what they have learned before

- Use what they observe as data in research or to make plans for the future

Associating with similar events and developing behavior about what to do when faced with such an event (MoNE, 2005, p. 50).

2005 SSCEC "People, Places and environments" learning area fifth grade achievements related to observation skills in the "Let's get to know our region" unit are listed below:

- He/She explains the impact of the climate seen in the region where he/she lives on human activities by giving examples from his daily life. 
- He/She associates geographical features with places where people in the area where they live extensively.

- He/She shows evidence of how people in the area where they live change and use the natural environment.

- He/She Associates the geographical features of the region with a disaster seen in the area in which it lives.

- Based on the oral and written elements of our culture, it exemplifies the effects of natural disasters on public life.

- He/She notices human activities that increase the damage of natural disasters seen in the area where he/she lives.

It can be said that when the above attainments are examined, the situations that require the student to observe their immediate environment are addressed and the applications that correspond to the knowledge and understanding dimension of the cognitive field, such as giving an example, noticing the student, are included.

2018 SSCEC "People, Places and environments" learning area achievements associated with observation skill in fifth grade are listed below:

SS.5.3.2. He/She explains the impact of the climate seen in the environment in which he/she lives on human activities by giving examples from his daily life.

SS.5.3.3. He/She gives examples of the natural features and effects of human features on population and settlement.

The place where he/she lived and the vegetation of his surroundings are described without going into detail.

Factors affecting the distribution of the population are emphasized. Evidence is shown of how humans change and exploit the natural environment.

SS.5.3.4. He/She questions the causes of disasters and environmental problems in the environment in which he lives.

SS.5.3.5. Explain the effects of natural disasters on public life with examples. (MoNE, 2018, p. 17-18).

As with the attainments in 2005 , the observation related to the immediate environment is given. But these achievements include practices that correspond to the knowledge, understanding dimension of the cognitive field, such as giving an example, explaining, as well as an application that should higher-level thinking skills, such as questioning, to work.

Studies on observational skill in social studies education were examined and studies on teacher opinion (Yıldız, 2016) and student perception (Ablak, 2017; Filoğlu, 2018), teacher, student and parent opinion (Kıbıcl, 2019) and skill teaching (Taş, 2008) were found. Ylldız (2016) concluded in his study that MoNE resources are insufficient to acquire the relevant skills in line with the views of the teacher. Filoglu (2018), who conducted research on students in terms of field-specific skills included in the 2005 Social Studies course curriculum, which also included observation skills, found that students can always perform these skills. In another 
study conducted on students (Ablak, 2017), student perceptions of field-specific skills were examined and as a result of the research, it was found that there are a number of deficiencies in student perceptions related to these skills. A study conducted on teachers, students and parents (Kıbicl, 2019) concluded that the skill that both teachers and students find most important in field-specific skills is observational skill.

A very limited number of studies have been found on observation skills, which are one of the skills intended to be acquired in the social studies course and which are included in both the 2005 and 2018 SSCEC. In addition, only one study on how this skill, which is among the field-specific skills in the 2005 SSCEC, is included in textbooks (Çelikkaya and Kürümlüoğlu, 2017) is an important consideration. But this study is not a study specific to observation skills, it is aimed at how field skills are considered in textbooks, and observation skills are also one of the skills studied. Therefore, the main purpose of the study is 2007 and 2020 edition fifth grade class are a comparative study of the status of observation skills in questions contained in social studies textbooks.

\section{Methodology}

\section{Model of the Research}

In this research, the document review method was used in accordance with the qualitative research approach. In the document review, written materials with information about the facts contained in the research are analyzed, and the authenticity of the documents is an important consideration (Ylldırım and Şimşek, 2008). However, textbooks on history and social issues can be the subject of study in both social sciences and Educational Sciences (Ulutaş, 2017). Based on this, the research documents are published in two different 2007 and 2020. 5. grade in the class is composed of textbooks and these documents were originally and originally developed for the social studies course by a commission. These documents are available from schools and the EBA online education platform.

\section{Data Collection Tools}

The research was conducted by examining two different fifth grade textbooks published in 2007 and 2020. The reason for selecting textbooks with 2007 and 2020 editions in the study is that the SSCEC was changed in 2005 and 2018. The 2007 edition book was chosen because it was the first book to be reached in print or electronic form after the publication of this program, and the 2020 edition book was chosen because it was the most current book. The reason for choosing the fifth class as the class level is as a direct skill, observation skills were included at this grade level in both 2005 and 2018 SSCEC.

The data collection tools of this research are MoNE publishing (Karagöz, Tekerek, Kaya, Azer, Alıç, Yllbat, Koyuncu and Ulusoy, 2007) and Ata publishing (Harut, 2020).

\section{Data Analysis}

Descriptive analysis technique was used in this study. To Bailey according to (1982, Ref. Yıldırım and Şimşek, 2008), researchers who will use textbooks as a data 
source can analyze research data using the stages of selecting samples from the data subject to analysis, developing categories, determining the analysis unit, and digitizing. In this research, four-stage data analysis was used as textbooks constitute the data source. In the first stage, the sample was determined by selecting the class level, year and skill. In the second stage, it was determined that the skill should be included in the textbooks. In the third stage, as a unit of analysis, questions about the ability to observe the questions were identified, and as a result of these analyses, the fourth stage, digitization, was performed. First, the frequencies of the questions associated with observation skills were determined in the questions. After accessing the numerical data, it was attempted to determine the status of observing the questions contained in the textbooks by calculating the percentage. It was then determined which step the questions were aimed at the observation skill. These steps were created by the MoNE (2005) and are listed below:

1. Attention to events and phenomena around it.

2. Detect events and phenomena around it.

3. Accurately and impartially identify events and facts around it.

4. Explain the causes and consequences of surrounding events and cases.

5. Be able to question the reasons and predict the consequences of what they observe.

6. Ability to establish relationships between events and phenomena, reveal similar or different aspects.

7. Record and transfer what you observe.

8. Ability to compare and link what they observe with what they have learned before.

9. Use what they observe as data in research or to make plans for the future.

10. Associating with similar events and developing behavior about what to do when faced with such an event.

Finally, the two textbooks are compared in terms of questions aimed at attainment observation skills. The researcher can ensure the reliability of the research by enriching it with direct citations (Yıldırım and Şimşek, 2008); therefore, direct references of parts of the textbooks containing the ability to observe are included.

\section{Findings}

\section{Findings About the First Sub-Problem}

In the social studies textbook published in 2007 under this heading, questions and levels asked about an attainment observation skill are given.

Below are images and levels of questions about observation skills in the 2007 published social studies textbook. The images numbered in the table will be discussed in detail later. In the textbook, questions about observation skills are figurely named in the table, as they are given in figure form. This is because there 
are parts where there is more than one problem, and these parts are addressed together.

Table 1

Images and Levels with Questions about Observation Skills

\begin{tabular}{|c|c|c|c|c|c|}
\hline $\begin{array}{l}\text { Grade/ } \\
\text { Figure }\end{array}$ & $\begin{array}{l}\text { Grade } \\
\text { Attention } \\
\text { to events } \\
\text { and } \\
\text { phenomen } \\
\text { a around } \\
\text { it }\end{array}$ & $\begin{array}{l}\text { Grade } \\
\text { Detect } \\
\text { events } \\
\text { and } \\
\text { phenomen } \\
\text { a around } \\
\text { it }\end{array}$ & $\begin{array}{l}\text { Grade } \\
\text { Accurate } \\
\text { and } \\
\text { impartial } \\
\text { identificatio } \\
\text { n of } \\
\text { surroundin } \\
\text { g events } \\
\text { and } \\
\text { phenomena }\end{array}$ & $\begin{array}{l}\text { Grade } \\
\text { Explain the } \\
\text { causes and } \\
\text { consequences } \\
\text { of surrounding } \\
\text { events and } \\
\text { cases }\end{array}$ & $\begin{array}{l}\text { 6. Grade } \\
\text { Ability to establish } \\
\text { relationships } \\
\text { between events and } \\
\text { phenomena, reveal } \\
\text { similar or different } \\
\text { aspects }\end{array}$ \\
\hline Figure 1 & - & 1 & 1 & 4 & - \\
\hline Figure 2 & 1 & 1 & 1 & - & 1 \\
\hline Figure 3 & - & - & - & 1 & - \\
\hline Figure 4 & - & - & - & 1 & - \\
\hline Figure 5 & - & - & - & 1 & - \\
\hline Figure 6 & - & - & - & 1 & - \\
\hline Figure 7 & - & 1 & - & - & - \\
\hline Figure 8 & - & 4 & - & - & - \\
\hline Figure 9 & - & 3 & 1 & - & - \\
\hline Total & 1 & 10 & 3 & 8 & 1 \\
\hline
\end{tabular}

As shown in Table 1, Six questions in figure 1 are one second level, one third level, and four fourth level; three questions in figure 2 are one first level, one second level, one third level; a fourth level question in figure 3; a fourth level question in figure 4; a fourth level question in figure 5; a fourth level question in figure six, a second level question in figure 7; four second level questions in figure 8 and three second level questions in figure 9 , a third level question.

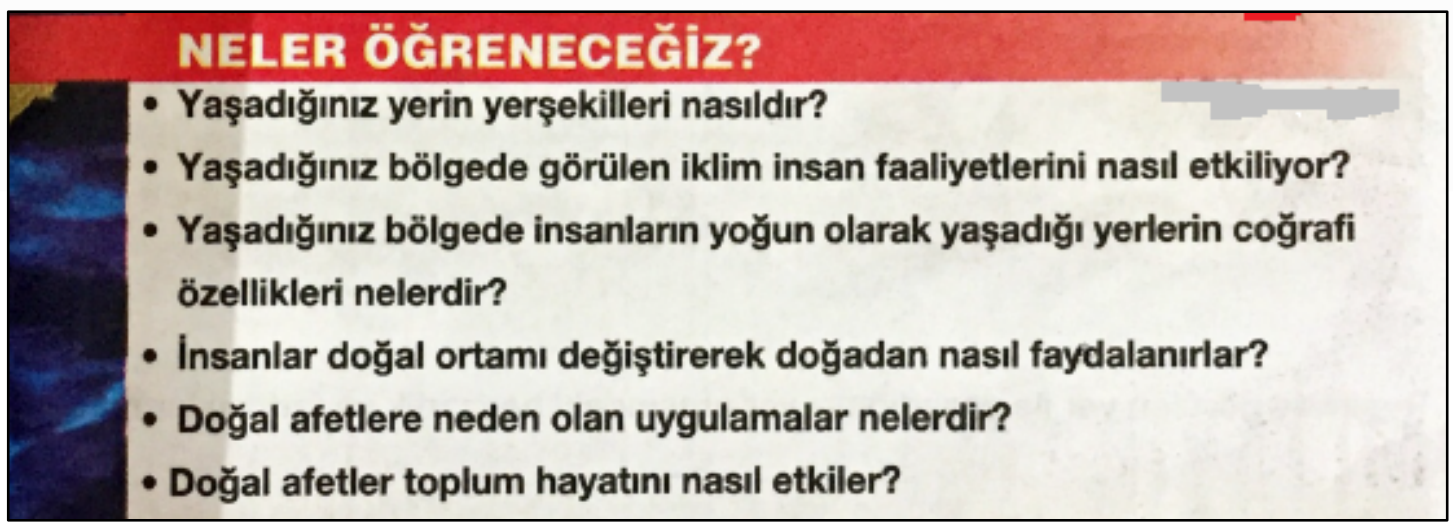

Figure 1. (Karagöz at. Al., 2007, p. 71)

When questions related to figure observation skills were examined, it was concluded that the first question was related to the second level, the second question was related to the fourth level, the third question was related to the fourth level, the fourth question was related to the third level, the fifth question was related to the fourth level, and the sixth question was related to the fourth level. He/ she also said, 
" What are we going to learn? it seems that these six questions addressed under the heading "are questions aimed at revealing students' preliminary knowledge. In this way, it will be possible to determine what students know based on their observations and to make more observations by arousing curiosity about what they will learn within the unit.

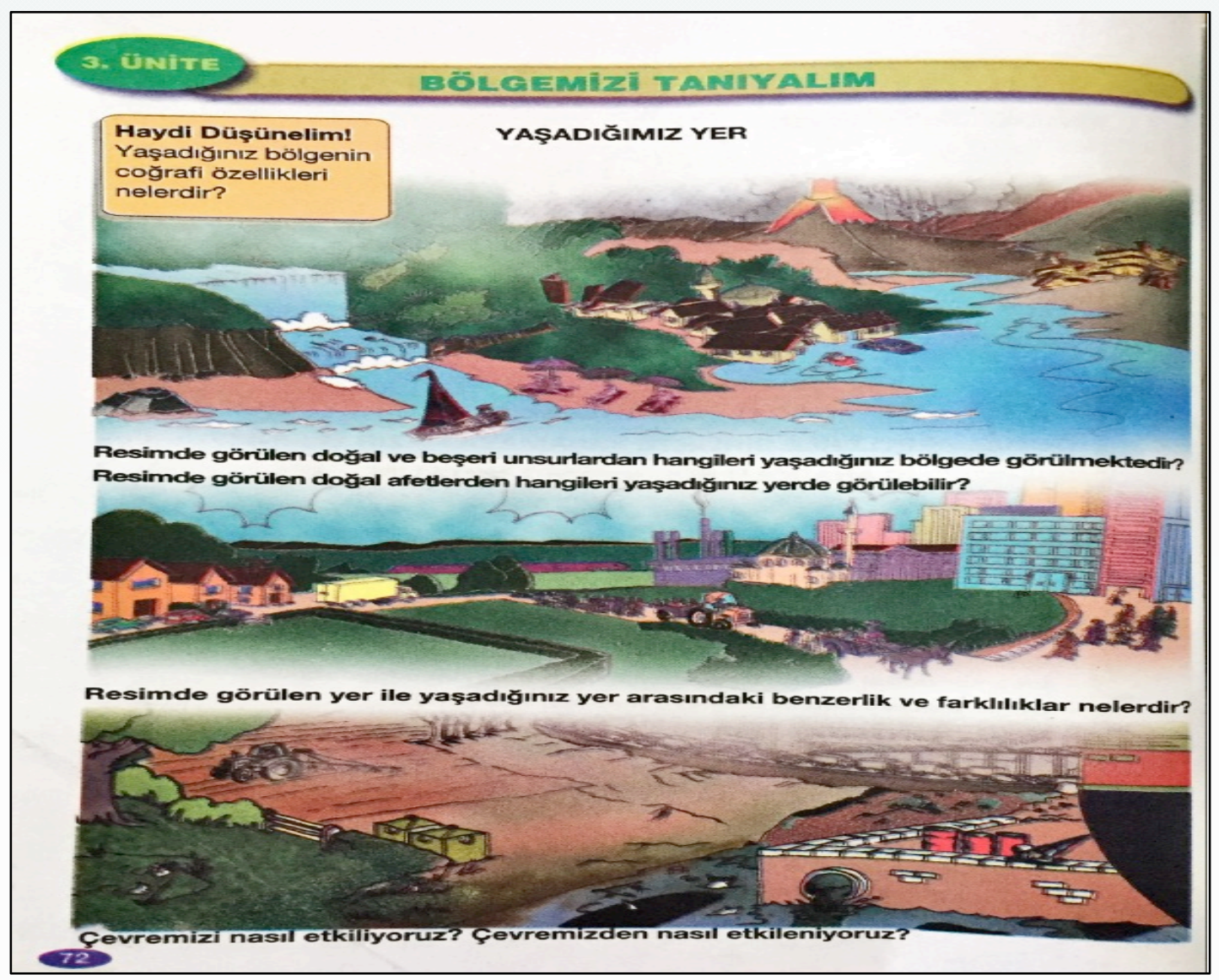

Figure 2. (Karagöz at. Al., 2007, p. 72)

When the questions related to the observation skill contained in the figure two were examined, it was concluded that the first question was related to the first level, the second question was related to the second level, the third question was related to the sixth level, and the fourth question was related to the third level. Here are the questions at the beginning of the unit, and it was desired to measure both the preliminary information and increase their interest in the course by drawing the attention of the students with the figures. Students were asked to establish a relationship between their observations and the situations found in the figure and asked questions about the highest level of observation skills contained in the 2007 published book.

\section{Sizin yaşadığınız yerin yerleşim yeri olarak seçiminde o yerin hangi coğrafi özellikleri etkili olmuş olabilir?}

Figure 3. (Karagöz at. al., 2007, p. 75) 
When the question associated with the observation skill in the figure third was examined, it was concluded that it was related to the fourth level. Here, students were asked a question that they had to answer to work on their observations of a situation in their immediate vicinity to measure whether they understood the information provided.

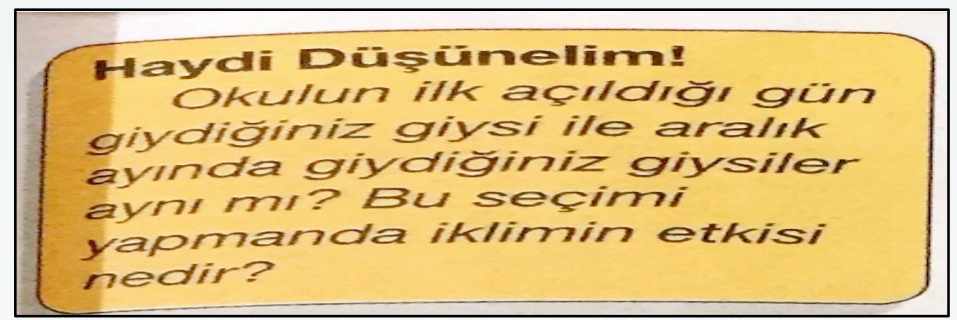

Figure 4. (Karagöz at.al., 2007, p. 79)

When the question associated with the observation skill in the figure quadrant was examined, it was concluded that it was related to the fourth level. Here, students were asked a question to measure their prior knowledge and asked to give answers based on their observations.

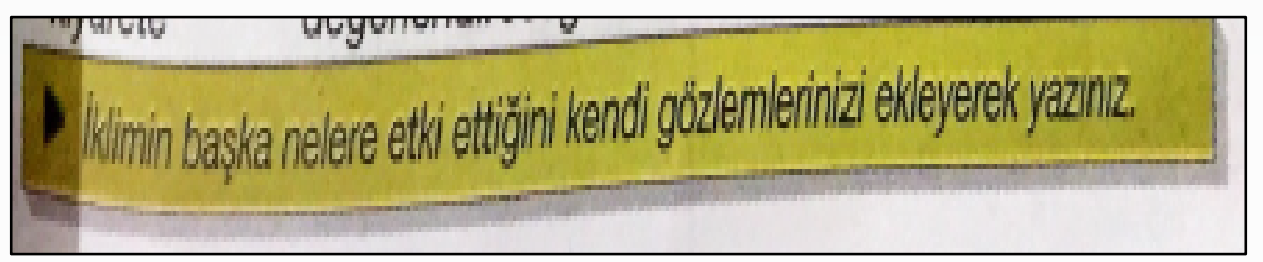

Figure 5. (Karagöz at. al., 2007, p. 79)

When the question associated with the observation skill contained in the figure fifth was examined, it was concluded that it was related to the fourth level. Students should answer this question based on their observations other than the information provided.

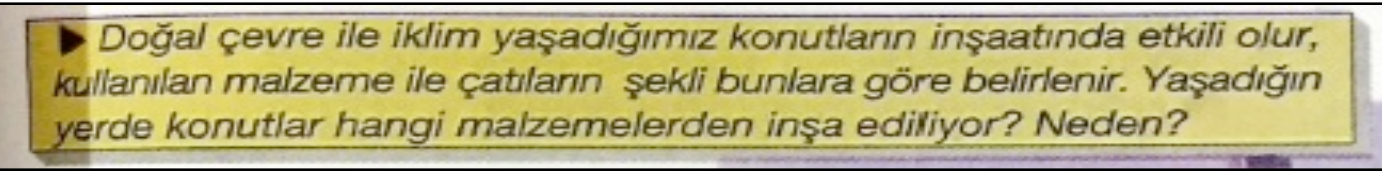

Figure 6. (Karagöz at. al., 2007, p. 83)

When the question associated with the observation skill contained in the figure fifth was examined, it was concluded that it was related to the fourth level. Students should answer this question based on their observations other than the information provided.

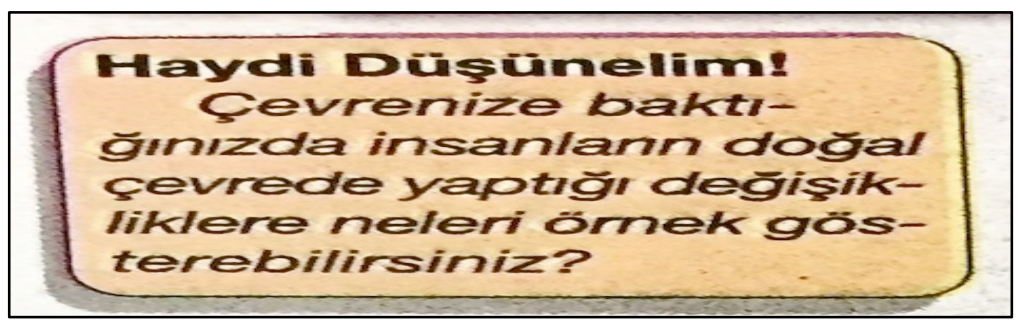

Figure 7. (Karagöz at. al., 2007, p. 86) 
When the question associated with observation skill in figure seven was examined, it was concluded that it was related to the second level. Here, students are asked a question aimed at revealing their preliminary knowledge.

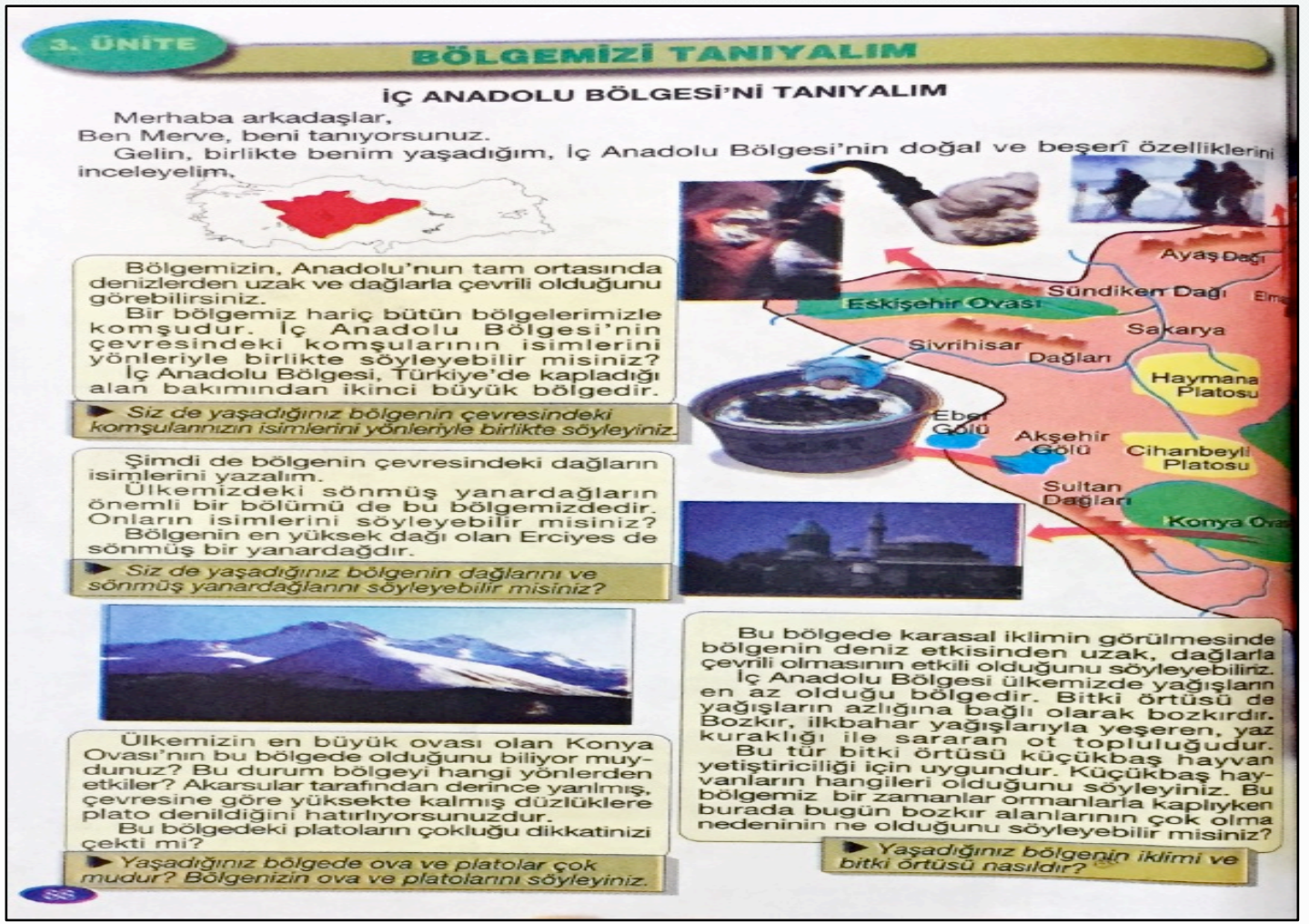

Figure 8. (Karagöz at. al., 2007, p. 88)

When the questions related to the observation skill contained in the figure eight were examined, it was concluded that all the questions were related to the second level. Here, students were asked to give examples based on their observations of the environment in which they lived, presenting an example to determine whether they understood the information provided.

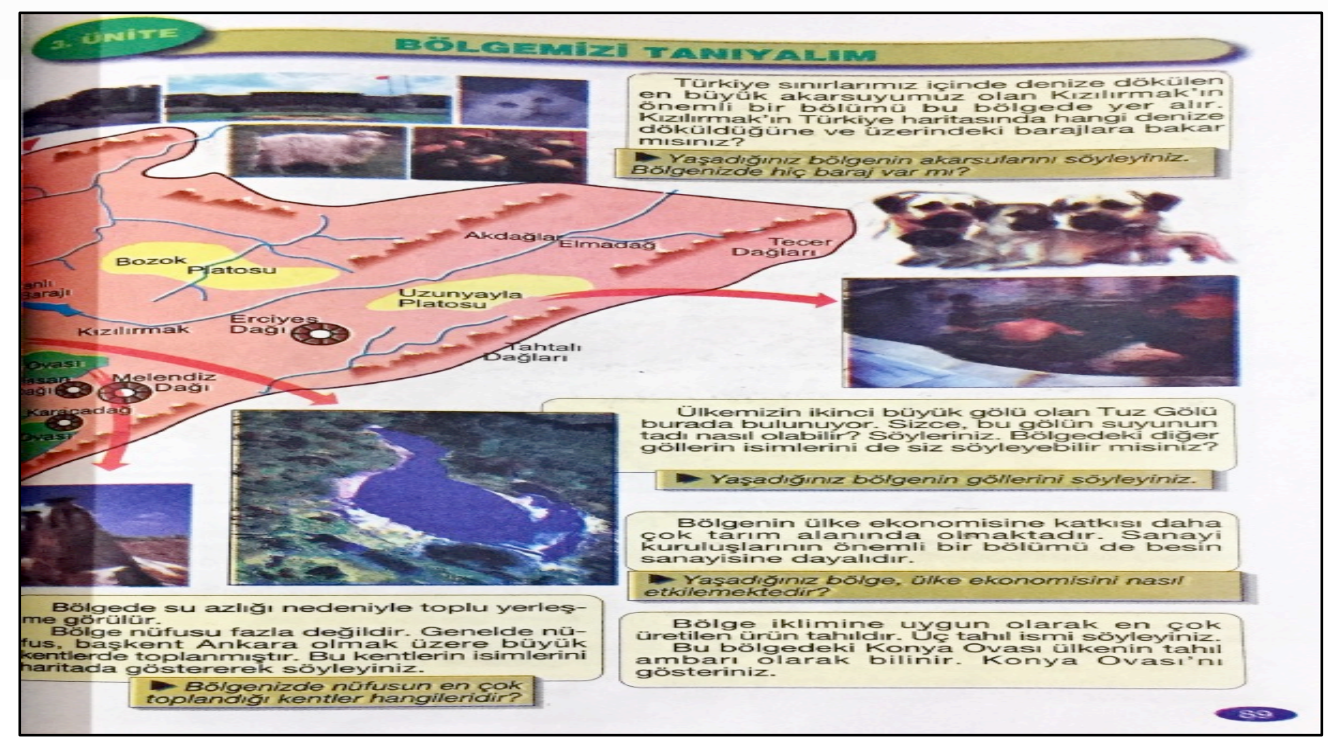

Figure 9. (Karagöz at. al., 2007, p. 89) 
Questions related to the observational skill contained in the figure nine are examined: "How does the region in which you live affect the country's economy?"it has been concluded that all other questions are related to the second level and the question is related to the third level. As mentioned earlier in this study, which is a continuation of the previous study, it was attempted to measure whether they understood the given information.

\section{Findings About the Second Sub-Problem}

In the social studies textbook published in 2020 under this heading, the questions and levels asked about attainment observation skills are given.

Below are images and levels of questions about observation skills in the social studies textbook published in 2020. The images numbered in the table will be discussed in detail later.

Table 2

Images and Levels with Questions about Observation Skills

\begin{tabular}{|c|c|c|c|c|c|}
\hline Grade/ & Grade & Grade & Grade & 4. Grade & 9. Grade \\
\hline Figure & $\begin{array}{l}\text { Attention } \\
\text { to events } \\
\text { and } \\
\text { phenome } \\
\text { na } \\
\text { around it }\end{array}$ & $\begin{array}{l}\text { Detect } \\
\text { events } \\
\text { and } \\
\text { phenome } \\
\text { na } \\
\text { around it }\end{array}$ & $\begin{array}{l}\text { Accurately } \\
\text { and } \\
\text { impartiall } \\
\text { y identify } \\
\text { events and } \\
\text { facts } \\
\text { around it }\end{array}$ & $\begin{array}{l}\text { Explain the } \\
\text { causes and } \\
\text { consequences } \\
\text { of } \\
\text { surrounding } \\
\text { events and } \\
\text { cases }\end{array}$ & $\begin{array}{l}\text { Use what they } \\
\text { observe as data in } \\
\text { research or to make } \\
\text { plans for the future }\end{array}$ \\
\hline $\begin{array}{l}\text { Figure } \\
10\end{array}$ & - & - & - & 1 & - \\
\hline Figure11 & - & - & 1 & - & - \\
\hline $\begin{array}{l}\text { Figure } \\
12\end{array}$ & - & 1 & - & - & - \\
\hline $\begin{array}{l}\text { Figure } \\
13\end{array}$ & - & 1 & - & - & - \\
\hline $\begin{array}{l}\text { Figure } \\
14\end{array}$ & - & - & - & - & 1 \\
\hline $\begin{array}{l}\text { Figure } \\
15\end{array}$ & 1 & - & - & 1 & 1 \\
\hline $\begin{array}{l}\text { Figure } \\
16 \\
\end{array}$ & - & 1 & - & - & - \\
\hline $\begin{array}{l}\text { Figure } \\
17\end{array}$ & - & - & - & 1 & - \\
\hline Total & 1 & 3 & 1 & 3 & 2 \\
\hline
\end{tabular}

In the figure, as shown in table two fourth-level question; Figure eleven in a thirdlevel question, as shown in figure at twelve, a second-level question; at the front end figure a second-level question; a question of the ninth level of the front quarter figure; the figure at fifteen first-level question, fourth-level question, the ninth-level question, figure Sixteen in a second-level question, and the fourth in the front seven figure level of a question is located. 
İnsanların televizyon, gazete ya da genel ağdan hava durumu tahminlerine bakmaIarının nedenleri ne olabilir?

Figure 10. (Harut, 2020, p. 66)

When the question associated with the observation skill contained in the figure was examined, it was concluded that it was related to the fourth level. Here, a question was asked to measure students ' preliminary knowledge.

\section{İnsanlar, hangi özelliklere sahip alanlara yerleşmeyi tercih eder?}

Figure 11. (Harut, 2020, p. 74)

When the question related to the observation skill contained in Figure Eleven was examined, it was concluded that it was related to the third level. In this question, an attempt was made to determine the preliminary information obtained by students based on their observations.

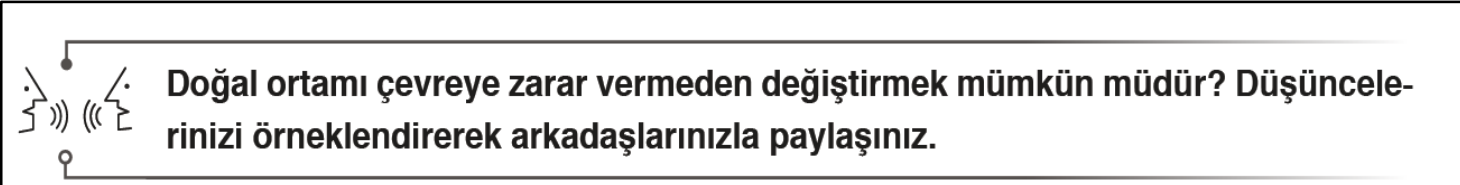

Figure 12. (Harut, 2020, p. 77)

When the question associated with the observation skill contained in Figure twelve was examined, it was concluded that it was related to the second level. Here, students were asked to think, taking into account the information given at the end of the subject, and express their thoughts by using observations and the information they learned in the course.

\section{Çevremizde yaşanan doğal afetler ve çevre sorunları bir tesadüf müdür?}

Figure 13. (Harut, 2020, p. 78)

When the question associated with the observation skill contained in the figure Thirteen was examined, it was concluded that it was related to the second level. Here, students' views on a situation in the immediate area were taken to measure both their preliminary information and draw attention to the subject. 


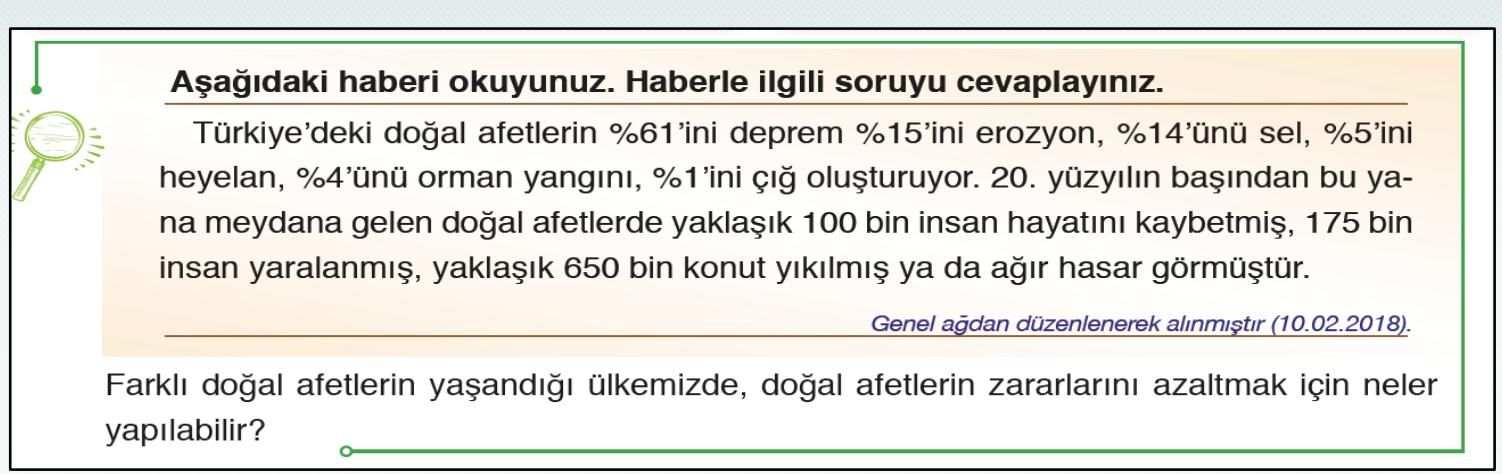

Figure 14. (Harut, 2020, s. 79)

When the question associated with the observation skill in Figure fourteen was examined, it was concluded that it was related to the ninth level. Here is one of the highest-level questions about the ability to observe in both books. Students can also develop suggestions by using the knowledge learned in the course when answering this question.

\section{Öğrendiklerimi Uyguluyorum}

Aşağıdaki soruların cevaplarını defterinize yazarak arkadaşlarınızla paylaşınız.

1. Yaşadığınız yerin özellikleri hangi doğal afetin ortaya çıkmasında etkili olmuştur?

2. Yaşadığınız yerde görülen çevre sorunları hangileridir? Bu sorunlara karşı ne gibi önlemler alınabilir?

Figure 15. (Harut, 2020, s. 81)

When the questions related to the observation skill contained in figure fifteen were examined, it was concluded that the first question was related to the fourth level and the second question was related to the first and ninth levels. As can be seen from the title "I practice what I have learned" here, students should answer questions using both their observations and the knowledge attainmented in the course. However, both books contain another of the highest-level questions about the ability to observe.

\section{Doğal afetlere maruz kalan insanlar hangi duyguları hisseder? Düşüncelerinizi arkadaşlarınızla paylaşınız.}

Figure 16. (Harut, 2020, p. 82)

When the question associated with the observation skill contained in figure sixteen was examined, it was concluded that it was related to the second level. Here, a question was asked to measure students ' preliminary knowledge. 


\section{- Doğal afetler, toplum hayatının başka hangi alanlarını olumsuz yönde etkiler? \\ క))) (( $($ 己 Düşüncelerinizi arkadaşlarınızla paylaşınız.}

Figure 17. (Harut, 2020, p. 84)

When the question associated with the observation skill contained in figure seventeen was examined, it was concluded that it was related to the fourth level. As the word "other" implies here, students were asked to share the information they attainmented based on their observations in addition to the information they learned in the course.

\section{Findings about the Third Sub-Problem}

Under this heading, Social Studies textbooks published in 2007 and 2020 include a comparison of the questions they ask to gain observation skills.

Table 3

Question Numbers on Observation Skill

\begin{tabular}{ll}
\hline Year & Question \\
\hline 2007 & 23 \\
\hline 2020 & 10 \\
\hline
\end{tabular}

According to table three, twenty-three questions about observation skills are included in the 2007 edition of the social studies textbook, and ten questions are included in the 2020 edition of the textbook. Accordingly, compared to the 2020 edition textbook, more questions about observation skills were included in the 2007 edition textbook.

Table 4

Questions About Observational Skill Levels

\begin{tabular}{lllll}
\hline Grade/Year & \multicolumn{2}{l}{2007} & 2020 & \\
\cline { 2 - 5 } & $\mathrm{n}$ & $\%$ & $\mathrm{n}$ & $\%$ \\
\hline Grade & 1 & 4,3 & 1 & 10,0 \\
\hline 2. Grade & 10 & 43,5 & 3 & 30,0 \\
\hline Grade & 3 & 13,1 & 1 & 10,0 \\
\hline Grade & 8 & 34,8 & 3 & 30,0 \\
\hline 6. Grade & 1 & 4,3 & - & - \\
\hline 9. Grade & - & - & 2 & 20,0 \\
\hline Total & 23 & 100,0 & 10 & 100,0 \\
\hline
\end{tabular}

According to Table 4, 1 of the 23 questions (4.3\%) related to observational skill contained in the 2007 published social studies textbook. Grade 2 (43.5\%) Grade 3 $(13.1 \%)$ out of 3 . Grade $4(34.8 \%)$ out of eight 6 . Grade and one (4.3\%). It has been determined to be Grade. In the 2020 edition social studies textbook, 1 out of 10 Questions (10.0\%). Grade, 2 of three (30.0\%). Grade 3 (10.1\%) Grade, 4 of three (30.0\%). Grade $9(20.0 \%)$ It has been concluded that it is Grade. According to this, in the 2007 published textbook, no more than 2 . To ask you to remove the part, at least 1 . and 6. Grade question; In the 2020 edition textbook, the maximum is 2 . and 
4. Grade, at least 1 . and 3. It was found that the question was included in the grade. As a Grade, it is seen that the textbook that contains the question at the top grade is a textbook with a 2020 edition.

\section{Result and Discussion}

In this study, it was aimed to examine the situation of inclusion of observation skills in the questions contained in the fifth-grade social studies textbooks published in 2007 and 2020. An area-specific skill that social studies teachers and secondary school students consider most important is the observation skill (Kıbıcl, 2019). In this context, the achievements related to the observation skills included in the 2007 and 2018 SSCEC were determined. As a result of the examination, six attainments in the 2005 SSCEC and four in the 2018 SSCEC were evaluated in relation to observation skills. In contrast, Aydemir and Adamaz (2017) attributed two of the fifth-grade attainments in the 2005 SSCEC to observational skill. But since these associated attainments were not specified in the study, the reason for the difference between the Associated attainments in this study and The Associated attainments in this study was not understood.

In this study, it was found that the attainments associated with observation skill, which were also discussed in the 2005 and 2018 SSCEC, were aimed at the immediate environment of students. Erdogan's (2019) statement that observations in the social studies course will facilitate skill acquisition when associated with daily life explains the fact that observation skills in programs are aimed at the immediate environment.

As a result of the research, twenty-three questions about observation skills are included in the social studies textbook published in 2007 and ten questions are included in the textbook published in 2020. Similarly, Çelikkaya and Kürümlüoğlu's (2017) study concluded that the activities were included in the 2015 published social studies textbook and that these activities were carried out with preparation for the subject, questions and activities in the subject. As the reason for the inclusion of more questions about observation skills in the 2007 edition textbook compared to the 2020 edition textbook; six achievements in the 2005 SSCEC related to observation skills can be shown, while four achievements in the 2018 SSCEC can be shown.

Questions as to the ability of observation in social studies textbooks examined and 2020 published 2007; 2007 in the textbook twenty-three of twelve questions $(\% 52,2)$ preliminary to uncover information for the ten $\%$ was 47.8$)$ the students with the knowledge you learned in the lesson they have learned in the lesson or in addition to the information obtained from observations it has been found that there are questions that they must use the information they have. 2020 four of the ten questions in the textbook (\% 40,0) preliminary to uncover information for six $(\%$ $60,0)$ the students with the knowledge you learned in the lesson they have learned in the lesson or in addition to the information obtained from observations it was inferred that there are questions that they must use the information they have. Accordingly, the 2007 edition textbook contains approximately the same number of questions from both categories, while the 2020 edition textbook contains more 
questions to determine whether they understand what they have learned in the course. In other words, questions related to observation skills are included both at the beginning of the teaching process and in the process in the 2007 published textbook, while the 2020 published textbook is included in the further teaching process.

In the 2007 edition textbook, it was found that the maximum number of questions at the second level, the minimum number of questions at the first and sixth levels, and in the 2020 edition textbook, the maximum number of questions at the second and fourth levels, the minimum number of questions at the first and third levels. Although the 2007 edition textbook contains more questions, it seems that the textbook that contains the highest level of questions at the level is the 2020 edition textbook. In relation to this result, Ylldiz (2016) concluded that the Ministry of National Education resources were insufficient to acquire the relevant skills in accordance with the views of the teacher in his study. The reason why the 2020 textbook is the book that contains the highest level of questions can be explained by the fact that there is an improvement in higher-level thinking skills such as questioning in the 2018 SSCEC. On the other, although observation skills are tried to be attainmented through questions in textbooks, it has been concluded that there are no questions for all ten levels of observation skills. This can be considered in relation to the 2005 SSCEC proposal that secondary school students should focus mainly on the first levels in order to attainment observation skills. But this indicates the point to focus on and shows that questions aimed at higher levels can also be included, although they are small in number, as can be seen in the textbooks to include the question associated with the ninth level.

\section{Suggestions}

Based on the conclusion that fifth-grade social studies textbooks do not have questions for all ten levels of observation skills, questions for all of these levels can be included, even if they differ in quantity in textbooks. Given that textbooks are distributed free of charge to students, it can be stated that the main source of secondary school students in general is important to the questions contained in the textbooks and textbooks.

\section{References}

Ablak, S. (2017). Examining students' perceptions on skill in social science teaching program (Unpublished doctoral thesis). Gazi University Institute of Educational Sciences, Ankara.

Ata, B. (2015). Social studies curriculum. C. Öztürk (Ed.), Social studies teaching democratic citizenship education (pp. 34-47). Ankara: PegemA Yayınları.

Aydemir, M., \& Adamaz, K. (2017). An analysis of achievements and activities included in the secondary school social sciences curriculum from the perspective of common and course-specific skills. International Journal of Field Education, 3(2), 37-59.

Çelikkaya, T., \& Kürümlüoğlu, M. (2017). Status of use in books field skills of the gained targeted in the 2005 social studies. Mustafa Kemal University Journal of Social Sciences Institute, 14(40), 141-158. 
Demircioğlu, İ., H. \& Akengin, H. (2012). Skills teaching related to time and space. In C. Öztürk (Ed.), Social studies teaching democratic citizenship education (pp. 187-224). Ankara: PegemA Yayınları.

Erdoğan, E. (2019). Observation. In B. Aksoy, B. Akbaba \& B. Kılcan (Eds.), Skill teaching in social studies (pp. 199-218). Ankara: PegemA Yayınları.

Filoğlu, S. (2018). The achievement situations of field skills in 2005 social studies curriculum according to the subjective perception of the students (Unpublished master thesis). Ahi Evren University Institute of Social Sciences, Kırșehir.

Güven, B. (2007). Basic concepts of teaching principles and methods. In Ş. Tan (Ed.), Teaching principles and methods (pp. 1-29). Ankara: PegemA Yayınları.

Harut, S. B. (2020). 5th grade social studies textbook. Ankara: Ata Yayıncllı.

Karagöz, D., Tekerek, M., Kaya, N., Azer, H., Alıç, M. D., Yılbat, B., Koyuncu, M., \& Ulusoy, K. (2007). Primary 5th grade social studies textbook. Ankara: MEB Yayıncllı.

Kıbıcl, N. (2019). Order of importance related to social studies course skills of social studies teachers, parents and students (Unpublished master thesis). Ușak University Institute of Social Sciences, Uşak.

Ministiry of National Education. (2005). Primary social studies course 6th-7th grade curriculum and guide-Draft printing. Ankara: MEB Yayıncllı.

Ministiry of National Education. (2018). Social studies lesson curriculum (Primary and secondary school 4th, 5th, 6th and 7th grades). Ankara: MEB Yayıncllı.

Observation. (n.d.) In Turkish Language Institution dictionaries online. Retrieved from https://sozluk.gov.tr/.

Tan, M., \& Temiz, B. K. (2003). The importance and role of the science process skills in science teaching. Pamukkale Üniversity Journal of Education Faculty, 13(13), 89-101.

Taş, H. İ. (2005). How to teach geography skills to students?. Eastern Geographical Review, (20), 45-58.

Ulutaş, B. (2017). Document analysis. In F. N., Seggie \& Y. Bayyurt (Eds.), Qualitative research methods, techniques, analysis and approaches (pp. 279-297). Ankara: Anı Yayıncılık.

Üker, H. (2009). In education, geography, to realize the level of skills needed to win, be reviewed in terms of student (Unpublished master thesis). Marmara University Institute of Educational Sciences, İstanbul.

Yıldırım, A., \& Şimșek, H. (2008). Qualitative research methods in the social sciences Sosyal bilimlerde nitel araştırma yöntemleri. Ankara: Seçkin Yayıncılık.

Yıldız, S. (2016). Reflections of social studies teachers on acquisition of observation skill in fifth grade social studies curriculum (A case study of Tokat central district) (Unpublished master thesis). Gaziosmanpaşa University Institute of Educational Sciences, Tokat.

\section{Biographical Statement}

Hülya KARAÇALI TAZE is an Assistant Professor at the Faculty of Education in Sinop University, Turkey where she works in the Turkish and Social Sciences Education Department. Her research interest includes social studies education, gender education, teaching history of women. 